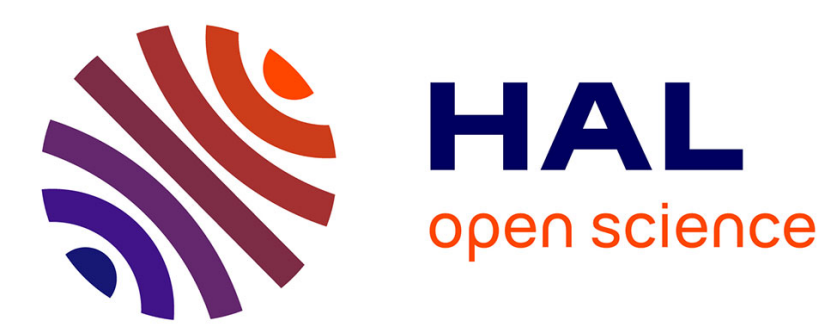

\title{
Neutral copper(I) complexes featuring phosphinesulfonate chelates
}

F. Vazart, P. Savel, C. Latouche, V. Barone, F. Camerel, T. Roisnel, Jean-Luc Fillaut, H. Akdas-Kilig, M Achard

\section{- To cite this version:}

F. Vazart, P. Savel, C. Latouche, V. Barone, F. Camerel, et al.. Neutral copper(I) complexes featuring phosphinesulfonate chelates. Dalton Transactions, 2016, 45 (15), pp.6566-6573. 10.1039/c6dt00593d . hal-01290442

HAL Id: hal-01290442 https://hal-univ-rennes1.archives-ouvertes.fr/hal-01290442

Submitted on 19 Apr 2016

HAL is a multi-disciplinary open access archive for the deposit and dissemination of scientific research documents, whether they are published or not. The documents may come from teaching and research institutions in France or abroad, or from public or private research centers.
L'archive ouverte pluridisciplinaire HAL, est destinée au dépôt et à la diffusion de documents scientifiques de niveau recherche, publiés ou non, émanant des établissements d'enseignement et de recherche français ou étrangers, des laboratoires publics ou privés. 


\title{
Neutral Copper(I) Complexes Featuring Phosphinesulfonate Chelates
}

\author{
F. Vazart, ${ }^{b}$ P. Savel, ${ }^{a}$ C. Latouche, ${ }^{b, c}$ V. Barone, ${ }^{b}$ F. Camerel, ${ }^{a}$ T. Roisnel, ${ }^{a}$ J. -L Fillaut, ${ }^{a}$ H. Akdas- \\ Kilig, ${ }^{*}$ and M. Achard ${ }^{a}$
}

\author{
a)UMR6226 CNRS, Institut des Sciences Chimiques de Rennes, Université de Rennes1, Campus de Beaulieu, 35042 Rennes Cedex (France) \\ Email : mathieu.achard@univ-rennes1.fr ; huriye.akdas@univ-rennes1.fr \\ b) Scuola Normale Superiore, piazza dei Cavalieri 7, I-56126 Pisa, Italy. \\ c) Institut des Matériaux Jean Rouxel (IMN), Université de Nantes, CNRS, 2 rue de la Houssinière, BP 32229, 44322 Nantes Cedex 03, France
}

The reaction of diphenylphosphinobenzenesulfonic acid with copper(I) oxide resulted in the formation of the new neutral dimeric copper(I) complex $\left\{\mathrm{Cu}_{2}(\mathrm{DPPBS})_{2} \cdot(\mathrm{MeOH})_{2}\right\}$. X-ray diffraction studies revealed that the complex has a dimeric structure and a pyramidal trigonal geometry around the copper atom which contains coordinated methanol molecules at the copper centers. Cleavage of the dimer by reaction with various bipyrimidines enabled the preparation of the corresponding well-defined heterotopic mononuclear $\left[\mathrm{Cu}\left(\mathrm{P}^{\wedge} \mathrm{O}\right)\left(\mathrm{N}^{\wedge} \mathrm{N}\right)\right]$ and dinuclear $\left\{\left(\mathrm{P}^{\wedge} \mathrm{O}\right) \mathrm{Cu}\left(\mathrm{N}^{\wedge} \mathrm{N}\right) \mathrm{Cu}\left(\mathrm{P}^{\wedge} \mathrm{O}\right)\right\}$ complexes. X-ray crystal structure determination shows these to have distorted tetrahedral geometries. Their absorption and emission properties were investigated experimentally and photophysical data were also confirmed by DFT and TD-DFT calculations. Owing to the methanol molecules, the neutral crystalline dimer $\left\{\mathrm{Cu}_{2}(\mathrm{DPPBS})_{2} \cdot(\mathrm{MeOH})_{2}\right\}$ displays green reversible photoluminescence upon UV irradiation in the solid state with an absolute luminescence quantum yield of 0.51 .

\section{Introduction}

Copper(I) complexes are of considerable interest with respect to their intriguing photophysical properties and possible utilization in material sciences, from solar energy conversion, ${ }^{[1]}$ probes, ${ }^{[2]}$ sensors, ${ }^{[3]}$ OLED $^{[4]}$ to photocatalysis. ${ }^{[5]}$. A lot of effort has been devoted to tune the photophysical properties, and stability of mononuclear cationic copper(I) complexes. ${ }^{[1,6]}$ In particular, the appropriate selection of $\mathrm{N}$-heterocyclic chelating ligands appeared as one key point to tune and improve the luminescence properties of cationic mono $\mathrm{Cu}(\mathrm{I})$ species, which can be highly affected via the steric, electronic, and conformational effects of the coordinated chelates. Additionally, the auxiliary ligands such as phosphine also have great effects on these emissive properties. The introduction of diphosphines with specific flexibility and bite angles, in contrast to triphenylphosphine, prevents or minimizes the flattened geometry of the excited state and result in emission in solution with a quantum yield enhancement, and longer lifetime. ${ }^{[7,8]}$ Meanwhile, one drawback of some $\left[\mathrm{Cu}\left(\mathrm{P}^{\wedge} \mathrm{P}\right)\left(\mathrm{N}^{\wedge} \mathrm{N}\right)\right]^{+}$complexes lies in the equilibrium in solution accounting on the side formation of $\left[\mathrm{Cu}\left(\mathrm{P}^{\wedge} \mathrm{P}\right)_{2}\right]^{+}$and $\left[\mathrm{Cu}\left(\mathrm{N}^{\wedge} \mathrm{N}\right)_{2}\right]^{+}$species. ${ }^{[7 e, 9]}$ Mononuclear cationic copper $(\mathrm{I})$ were also prepared by the use of $\mathrm{N}$-heterocyclic carbenes to afford tri- or tetra-coordinated copper(I) species circumventing these equilibriums. ${ }^{[10,11]}$ Neutral mono- to multinuclear-copper(I) species have been far less investigated. ${ }^{[10,12-22]}$ One way to access neutral copper(I) complexes involves the use of hybrid, poly- or di-phosphines, ${ }^{[12,13]}$ halogen-bridged ligands ${ }^{[14-16]}$ or other templates ${ }^{[17-22]}$

It appeared to us that the introduction of phosphine-sulfonate ligands as hybrid phosphines could be an interesting alternative to both mono- and di-phosphine ligands. Such ligands enable interaction with Lewis acid or other transition metal complexes through one of the non-coordinated oxygen atom of the sulfonate moiety. ${ }^{[23]}$ Meanwhile, well-defined copper complexes featuring phosphine sulfonate chelates have never been reported, even if sulfonate chelates ranging from phosphinesulfonate to NHC-sulfonate have found broad applications in catalysis. ${ }^{[24,25]}$.

Herein we report the design and characterization of the first example of neutral copper(I) species featuring six membered phosphinesulfonate chelates giving access to the corresponding neutral mononuclear $\left[\mathrm{Cu}\left(\mathrm{P}^{\wedge} \mathrm{O}\right)\left(\mathrm{N}^{\wedge} \mathrm{N}\right)\right]$ and $\operatorname{dinuclear}$ $\left\{\left(P^{\wedge} \mathrm{O}\right) \mathrm{Cu}\left(\mathrm{N}^{\wedge} \mathrm{N}\right) \mathrm{Cu}\left(\mathrm{P}^{\wedge} \mathrm{O}\right)\right\}$ complexes.

\section{Results and discussion}

\section{Synthesis of Cu-1-4 and X-ray analyses}

Reaction of copper(I) oxide with Murray's ligand, DPPBSA (diphenylphosphinobenzensulfonic acid), ${ }^{[26]}$ in methanol solution resulted in the formation of a white precipitate which, after recrystallization, cleanly afforded a unique colourless compound, the dimeric $\left\{\mathrm{Cu}_{2}(\mathrm{DPPBS})_{2}\right.$. $\left.(\mathrm{MeOH})_{2}\right\}$ species, referred to in the following as $\mathbf{C u - 1}$, along with water as the only side product of the reaction (Scheme 1$)$. 


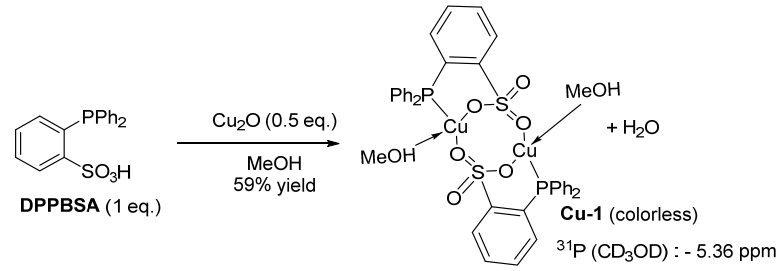

Scheme 1 Preparation of the Cu-1 dimer

The formation of a dimeric species was confirmed by single-crystal X-ray diffraction studies. Inside the complex, the copper atoms featuring the six-membered $\mathrm{P}, \mathrm{O}$ chelate are stabilized by one methanol molecule and one oxygen atom arising from the sulfonate moiety of the other chelate (Figure 1). The resulting eight membered-ring adopts a chair-chair conformation with pyramidal trigonal geometry around the copper atoms in which the oxygen atom of the sulfonate moiety occupies the apical position. It is noteworthy that the P1-Cu1-centroid (O21-O22) angle is $165.73^{\circ} .^{[7 \mathrm{~h}, 12 \mathrm{c}, \mathrm{e}]} \mathrm{NMR}$ spectroscopy has also confirmed the formation of a unique species at $-5.36 \mathrm{ppm}$ in ${ }^{31} \mathrm{P}$ NMR and the presence of coordinated methanol molecules highlighted by a broad peak located at $4.06 \mathrm{ppm}$ in ${ }^{1} \mathrm{H} \mathrm{NMR}\left(\mathrm{CD}_{2} \mathrm{Cl}_{2}\right)$.

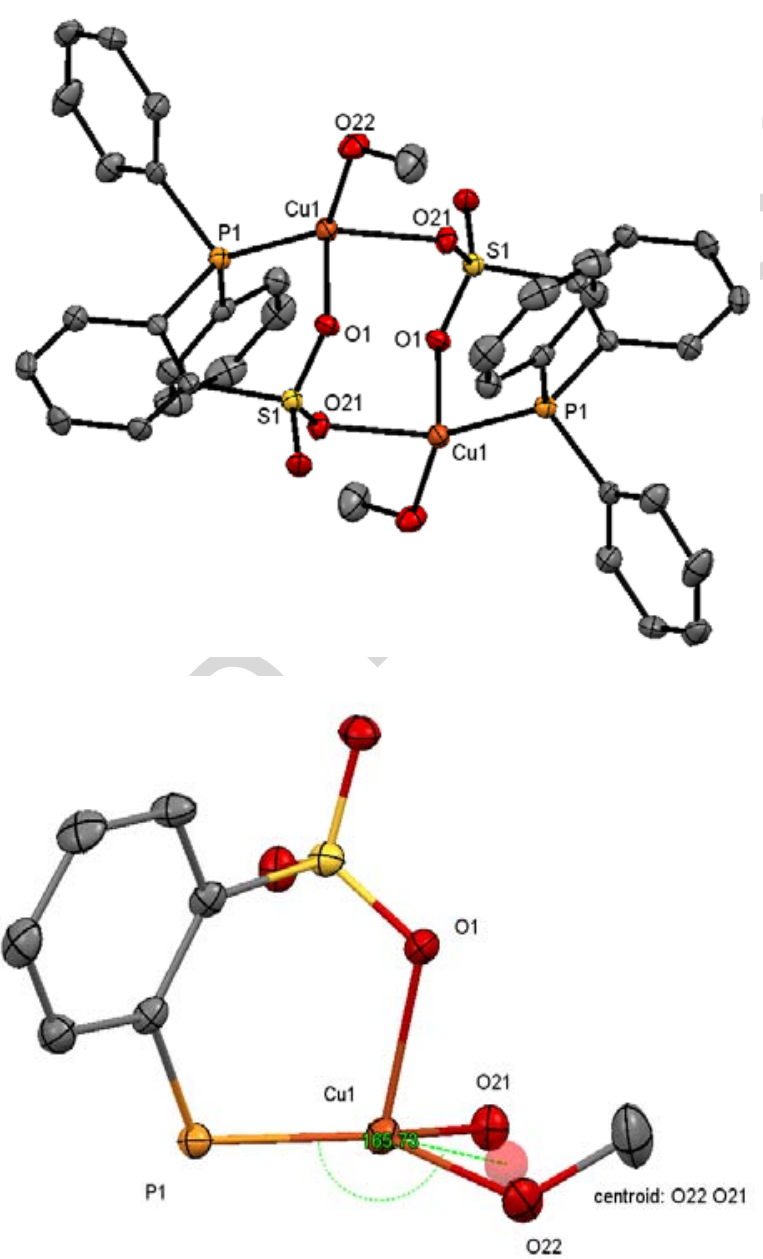

Fig. $1 \mathrm{X}$-ray structure of $\mathrm{Cu}-1.1 \mathrm{MeOH}$ (top). non coordinated methanol molecule as well as hydrogen have been deleted for clarity. Selected bond lengths $(\AA)$ and angles ( $\left.{ }^{\circ}\right), \mathrm{Cu}_{1}-\mathrm{P}_{1} 2.1525(7) ; \mathrm{Cu}_{1}-\mathrm{O}_{1} 2.190(2) ; \mathrm{Cu}_{1}-\mathrm{O}_{21} 2.099(2) ; \mathrm{Cu}_{1}-\mathrm{O}_{22} 2.040(2) ; \mathrm{S}_{1}-\mathrm{O}_{1}$ $1.458(2) ; \mathrm{S}_{1}-\mathrm{O}_{21} 1.468(2) ; \mathrm{O}_{1}-\mathrm{Cu}_{1}-\mathrm{P}_{1}$ 100.48(5); $\mathrm{P}_{1}-\mathrm{Cu}_{1}-\mathrm{O}_{22}$ 133.43(6); $\mathrm{O}_{1}-\mathrm{Cu}_{1}-\mathrm{O}_{21}$ 95.33(7); $\mathrm{O}_{1}-\mathrm{S}_{1}-\mathrm{O}_{21} 113.3(1) ; \mathrm{O}_{1}-\mathrm{S}_{1}-\mathrm{C}_{18} 107.0(1) ;$ $\mathrm{O}_{21}-\mathrm{S}_{1}-\mathrm{C}_{18} 105.0(1) ; \mathrm{Cu}_{1}-\mathrm{O}_{21}-\mathrm{S}_{1} 122.0(1) ; \mathrm{Cu}_{1}-\mathrm{O}_{1}-\mathrm{S}_{1} 113.5(1)$. CCDC 1417484 contains the supplementary crystallographic data for Cu-1. Simplified $\mathrm{X}$-ray structure around the copper atom (bottom). 


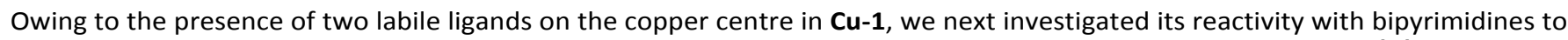
access the corresponding neutral mononuclear $\left\{\mathrm{Cu}\left(\mathrm{P}^{\wedge} \mathrm{O}\right)\left(\mathrm{N}^{\wedge} \mathrm{N}\right)\right\}$ and binuclear $\left\{\left(\mathrm{P}^{\wedge} \mathrm{O}\right) \mathrm{Cu}\left(\mathrm{N}^{\wedge} \mathrm{N}\right) \mathrm{Cu}\left(\mathrm{P}^{\wedge} \mathrm{O}\right)\right\}$ complexes. ${ }^{[1 \mathrm{a}]}$

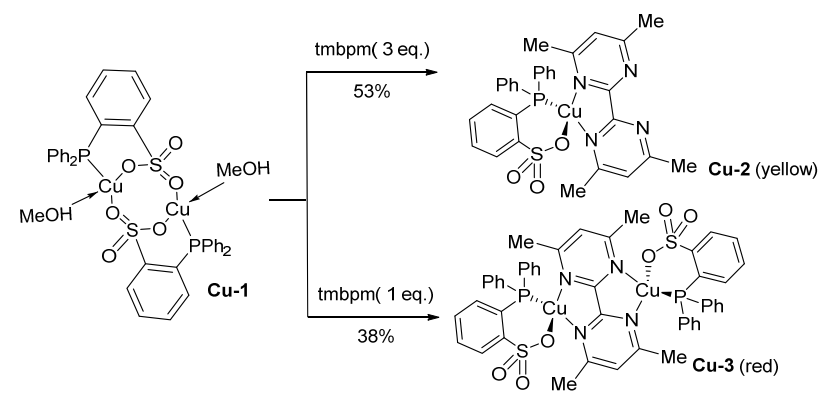

Scheme 2 Preparation of the heteroleptic mononuclear $\mathbf{C u}-\mathbf{2}$ and the dinuclear $\mathrm{Cu}-\mathbf{3}$ complexes.

Initial attempts with 2,2',4,4'-tetramethylbipyrimidine (tmbpm) in methanol resulted in the competitive formation of the corresponding mono- and di-nuclear copper complexes $\mathbf{C u - 2}$ and $\mathbf{C u - 3}$. Taking advantage of recent contributions ${ }^{[1 \mathrm{a}, 27]}$ on the selective preparation of cationic mono- and di-nuclear DPEPhos-copper(I) complexes, optimization of the reaction conditions using 3 eq. of tmbpm afforded the selective formation of the mononuclear $\{\mathrm{Cu}$ (DPPBS)(tmbpm)\} $\mathbf{C u}-\mathbf{2}$ complex in $53 \%$ yield. Owing to its very low solubility, the centrosymmetric dinuclear complex $\left\{\mathrm{Cu}(\mathrm{DPPBS})_{2}(\mathrm{tmbpm})\right\} \mathrm{Cu}-3$ was selectively obtained in the presence of an excess of $\mathbf{C u - 1}$ (Scheme 2). However, during these studies it was noted that the resulting Cu-3 is highly sensitive in solution and undergoes slow decoordination as noted by the slow reappearance of Cu-2 during NMR analyses. Interestingly, 4,4'-dimethyl-2,2'diphenyl-bipyrimidine (PhMebpm) bearing two phenyl groups prevented competitive dinucleation and reacted with $\mathbf{C u - 1}$ in a one pot manner to exclusively afford the corresponding neutral mononuclear copper(I) Cu-4 in 55\% isolated yield (Scheme 3).

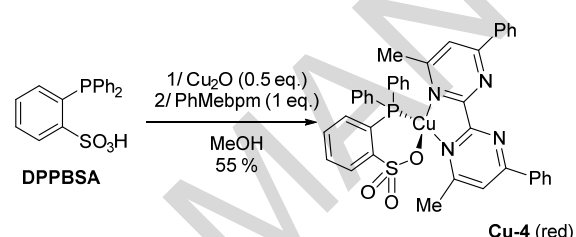

Scheme 3 Preparation of the heteroleptic mononuclear $\mathbf{C u}-\mathbf{4}$ complex.

The molecular structures of the aforementioned complexes were confirmed by X-ray crystallography on single crystals. The corresponding ORTEP views depicted in Figure 2 and 3 point out a distorted tetrahedral geometry around the copper centre for all the complexes and thus contrasting with the pyramidal trigonal geometry in Cu-1. Remarkably, use of the neutral dimer Cu-1 prevented side formation in solution of undesired $\left[\mathrm{Cu}\left(\mathrm{N}^{\wedge} \mathrm{N}\right)_{2}\right]^{+}$species.
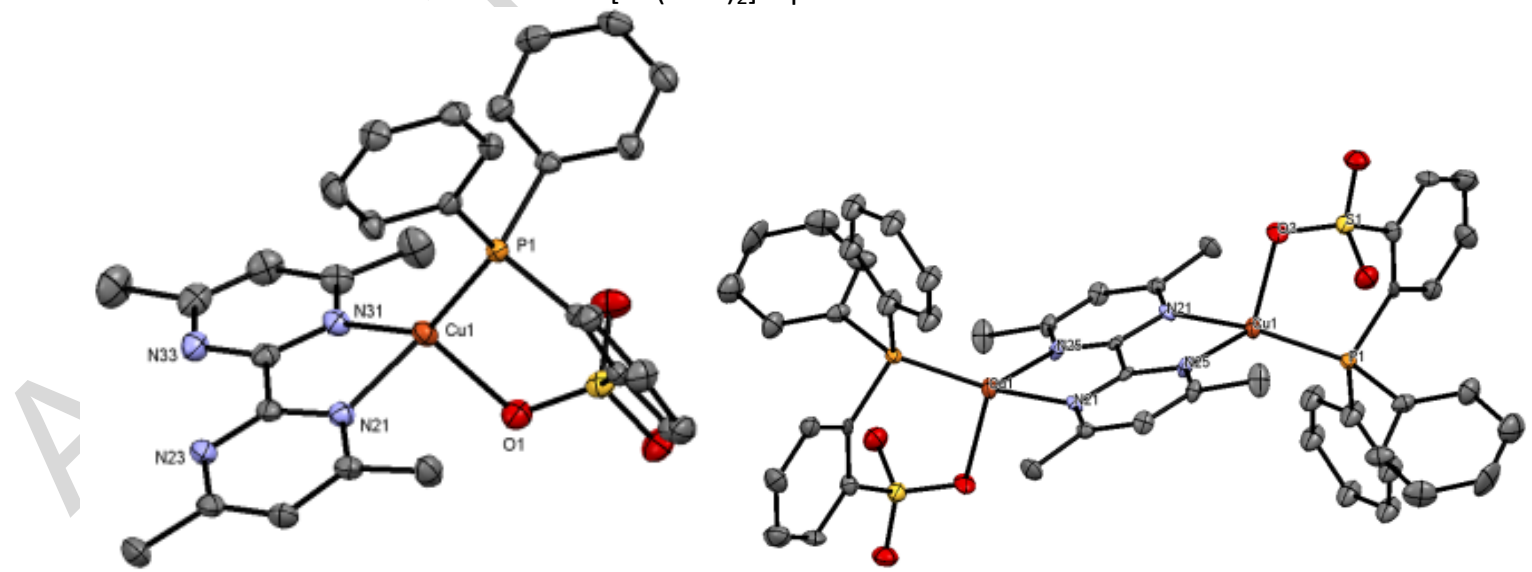

Fig. 2 ORTEP views of the mononuclear $\mathbf{C u}-\mathbf{2}$ (top) and the centrosymmetric $\mathbf{C u}-\mathbf{3}$ (bottom) with the principal atom labelling (thermal ellipsoid at 50\% probability level). CCDC 1417461 (Cu-2) and CCDC 1417460 (Cu-3) contains the supplementary crystallographic data.

Photophysical and theoretical results 
The main parameters characterizing experimental and calculated UV-Vis absorption spectra in dichloromethane solution spectra are reported in Table 1. The absorption spectrum of Complex Cu-1 displays a broad band at $270 \mathrm{~nm}$ attributed to metalperturbed intraligand $\pi-\pi^{*}$ and $n-\pi^{*}$ transitions centered on the phenyl ring of the DPPBS fragment. For Cu-2-4 complex we observe two distinct groupings and the spectra have similar shape to complexes described in previous works. ${ }^{[1 a, 27]}$ For Cu-2-4 $^{2}$ complexes in addition to the phenyl centred transitions, an

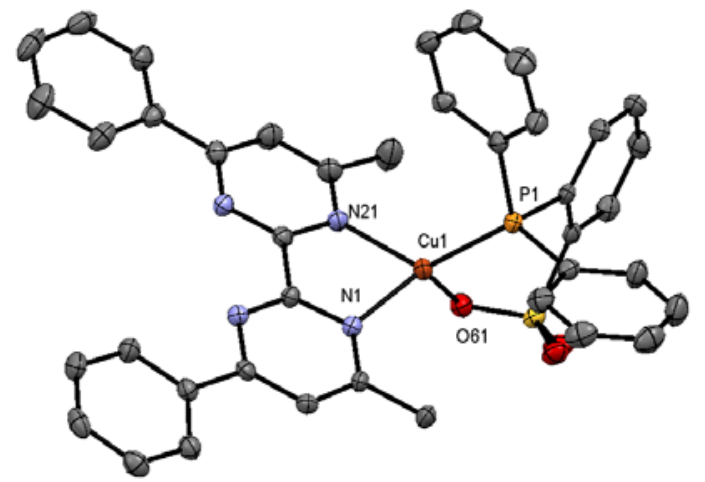

Fig. 3 X-ray molecular structure of Cu-4. CCDC 1417462 contains the supplementary crystallographic data for Cu-4.

Table 1 Experimental and calculated optical data.

\begin{tabular}{|c|c|c|c|c|}
\hline Compound & $\mathrm{Cu}-1$ & Cu-2 & $\mathrm{Cu}-3$ & $\mathrm{Cu}-4$ \\
\hline \multirow{2}{*}{$\begin{array}{c}\lambda_{\text {abs }}(\mathrm{nm})^{\mathrm{a}} \\
\left(\varepsilon_{\max }\right)^{b}\end{array}$} & \multirow[b]{2}{*}{270} & $320(\mathrm{sh}, 60)$ & $330(\mathrm{sh})$ & 305 (sh) \\
\hline & & $400(22)$ & $440^{c}$ & $405(24.8)$ \\
\hline \multirow{3}{*}{$\lambda_{\text {abs }}(n m)$ th. } & 286 & 290 & \multirow{3}{*}{$\begin{array}{l}381 \\
500\end{array}$} & \multirow{3}{*}{$\begin{array}{l}301 \\
445\end{array}$} \\
\hline & 306 & 340 & & \\
\hline & 346 & 436 & & \\
\hline$\lambda_{\mathrm{em}}(\mathrm{nm})^{d}$ & 515 & & - & - \\
\hline Stokes shift $\left(\mathrm{cm}^{-1}\right)$ & 9154 & & - & - \\
\hline \multicolumn{5}{|c|}{$\begin{array}{c}{ }^{\mathrm{a}} \text { in } \mathrm{CH}_{2} \mathrm{Cl}_{2} \cdot{ }^{\mathrm{b}} \text { Units }=10^{3} \mathrm{Mol}^{-1} \mathrm{~cm}^{-1} .{ }^{\mathrm{c}} \text { Not enough soluble. }{ }^{d} \text { in solid } \\
\text { state. } \mathrm{sh}=\text { shoulder }\end{array}$} \\
\hline
\end{tabular}

additional broad band between 400 and $440 \mathrm{~nm}$ is observed which can be ascribed to the copper to bipyrimidine charge transfer (MLCT) transition (Fig S1-S4). A shoulder around $320 \mathrm{~nm}$ is also observed and can be ascribed to the $\pi$ - $\pi^{*}$ intrabipyrimidine transition (ICT). Replacement of the methyl groups in Cu-2 on the bipyrimidine fragment by phenyls in Cu-4 does not give rise to change on the absorption spectrum. In the dinuclear complex $\mathrm{Cu}-3$ a significant red shift of the MLCT band $\left(\Delta \lambda=2273 \mathrm{~cm}^{-1}\right)$ is observed. Geometry optimizations of the ground electronic states of all complexes by methods rooted into the density functional theory (DFT) taking into account solvent effects by the polarizable continuum model (PCM) led to structures closely matching their experimental (X-ray) counterparts, except for slight differences for the $\mathrm{Cu} 1-\mathrm{O} 1\left(\mathrm{SO}_{3}\right)$ and the $\mathrm{Cu} 1-\mathrm{O} 22(\mathrm{MeOH})$ bonds in Cu-1 (Table S1-S2). This confirms the choice of both the functional (B3PW91) and the basis set (def2tzvp) performed on the grounds of previous experience. ${ }^{[28,29]}$ Vertical absorption spectra were next computed by the time dependent extension of DFT (TD-DFT) obtaining again good agreement with experiment but with a shift of wavelengths (see Table 1). Several aspects that lead to these discrepancies with respect to experimental data could take their origin from solvent aggregation, large system phenomenon which could provoke this disagreement on the absorption band positions. However, comparison of both experimental and simulated spectra demonstrated that the overall band shapes are nicely reproduced and the structural parameters are in good agreement with respect to the experimental parametric data. ${ }^{[30]}$ Complexes Cu1-4 were found to be nonluminescent in solution $\left(\mathrm{CH}_{2} \mathrm{Cl}_{2}, \mathrm{MeOH}, \mathrm{CH}_{3} \mathrm{CN}\right.$, toluene) upon excitation in the various absorption bands observed. Interestingly, the neutral crystalline dimer $\mathbf{C u - 1}$ display strong green photoluminescence upon UV irradiation in solid state (microcrystalline powder, Figure 4), with an absolute luminescence quantum yield of 0.51 presumably arising from mixed interligand excited states (Figure 5). The insufficient bite angle of DPPBSA with copper (around $100^{\circ}$ ) compared with DPEphos $\left(118^{\circ}\right.$ ) on the wellestablished cationic copper(I) complexes is probably responsible of this absence of emissivity both in solution and solid state for Cu-2, Cu-3 and $\mathrm{Cu}-4$. $^{[7]}$

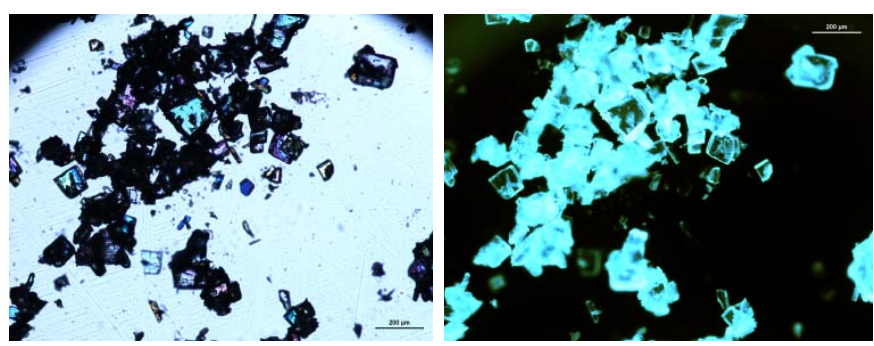

Figure 4 Optical microscopy pictures of $\mathbf{C u - 1}$ under normal light (left) and under irradiation (340-380 nm). 


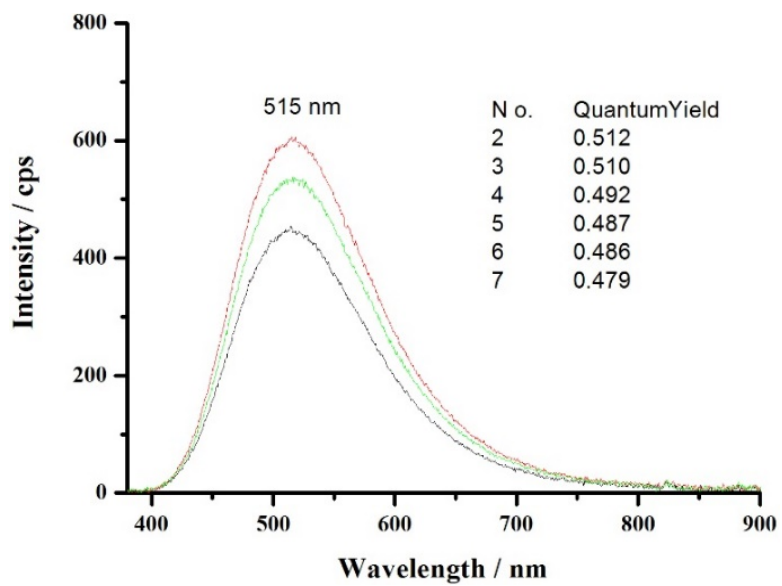

Figure 5. Absolute Quantum Yield of Cu-1 measured at the solid state with an integrated sphere (The decrease of the luminescence Quantum Yield is due to the departure of methanol during the successive measurements).

The absorption spectrum of $\mathbf{C u - 1}$ is slightly red-shifted to $350 \mathrm{~nm}$ in solid state. Temperature-dependent solid state luminescence studies show only a gradual decrease of the luminescence intensity from $-200{ }^{\circ} \mathrm{C}$ up to $120{ }^{\circ} \mathrm{C}$ without any shift of the emission maximum confirming the absence of thermofluochromism (Figure 6).

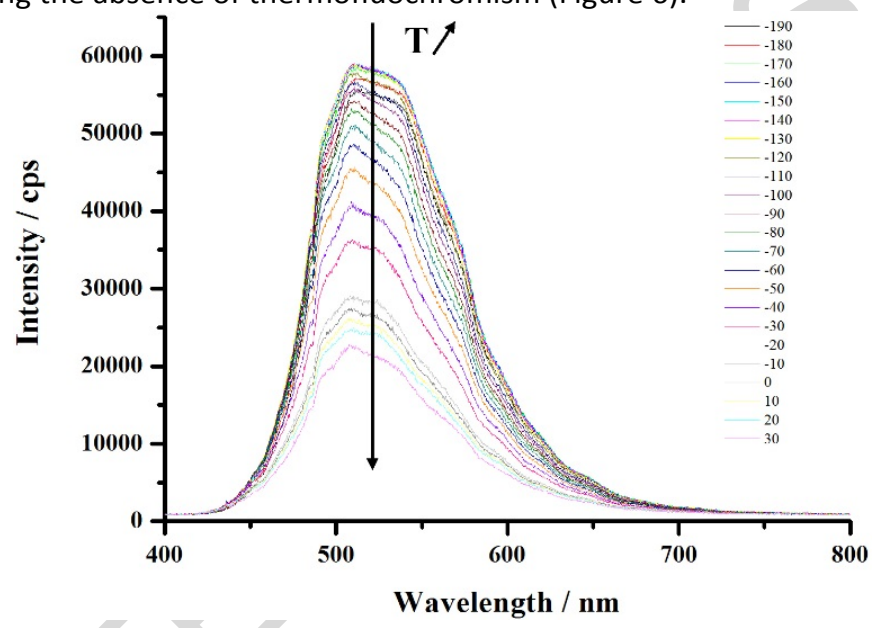

Figure 6. Effect of temperature (heating mode from -190 to $30^{\circ} \mathrm{C}$ ) on the emission of $\mathrm{Cu}-1$

Upon cooling from 30 to $-50{ }^{\circ} \mathrm{C}$, the emissivity of the $\mathrm{Cu}-\mathbf{1}$ dimer gradually increases again, without any shift of the emission maximum (Figure 7). Additionally, the interatomic $\mathrm{Cu}-\mathrm{Cu}$ distance of $3.975 \AA$ confirms the absence of cuprophilicity which tend to explain the absence of fluoro-thermochromism (Figure 1). ${ }^{[31]}$ Above $120{ }^{\circ} \mathrm{C}$, under inert atmosphere and due to the loss of the methanol molecules, the compound became non-luminescent and the luminescence is not restored upon cooling.

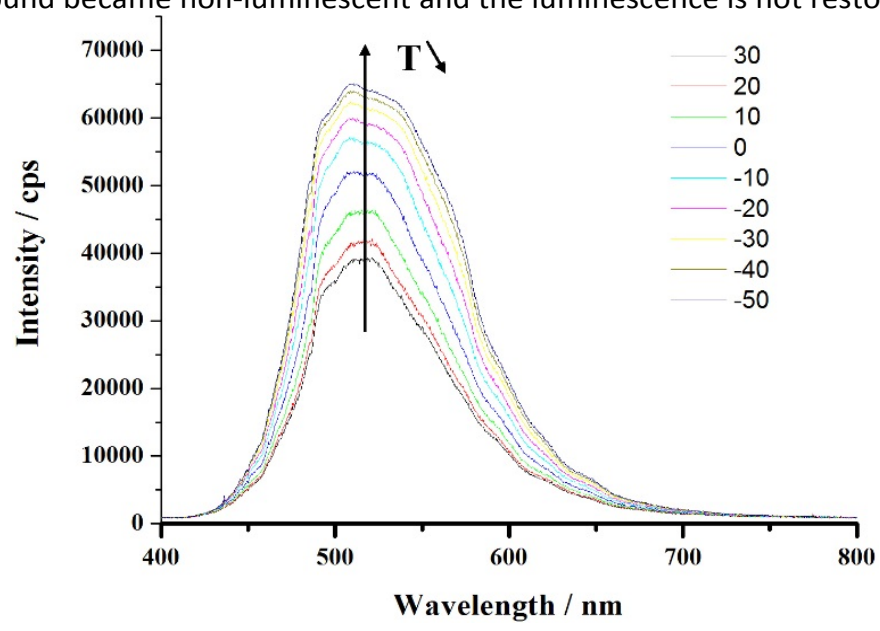


Figure 7. Effect of temperature (cooling mode from $30^{\circ} \mathrm{C}$ to $-50^{\circ} \mathrm{C}$ ) on the emission of $\mathbf{C u}-\mathbf{1}$

\section{Reversible photoluminescence}

Interested by this emissivity quenching owing to the loss of methanol molecules, we next investigated the possibility to develop a reversible photoluminescent system. Thus, heating well-defined $\mathbf{C u}-\mathbf{1}$ at $70{ }^{\circ} \mathrm{C}$ under vacuum to remove the methanol molecules resulted in the loss of emissivity of the resulting complex (Figure 8). Addition of small amount of methanol highlighted the immediate recovery of the emission properties. Additionally, NMR analyses demonstrated the reformation of Cu-1. Taken together, these experiments highlight the crucial influence of methanol molecules in the crystalline structure on the reversible photoluminescent properties. ${ }^{[32]}$ At this stage of this research, the loss of the coordinated methanol molecule on the copper atom in Cu-1 might be responsible on the reversible photoluminescent properties. However, a synergetic effect owing to the presence of uncoordinated methanol molecules in the crystalline thus preventing self-quenching cannot totally be excluded. ${ }^{\text {[3] }}$ 


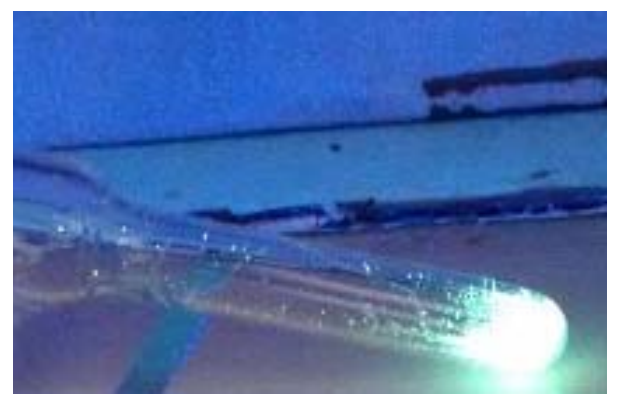

a/

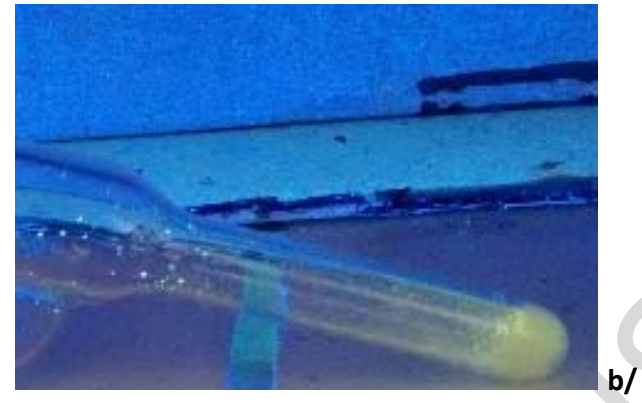

b/

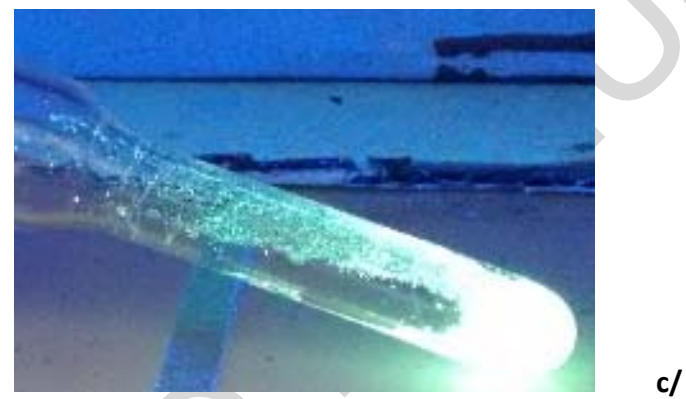

Figure 8. Reversible photoluminescence (UV irradiation, , $\lambda=312 \mathrm{~nm}$ ): $\mathrm{a} / \mathrm{Cu}-\mathbf{1} ; \mathrm{b} /$ vacuum $70^{\circ} \mathrm{C}, 20 \mathrm{mins} ; \mathrm{c} /$ addition of $\mathrm{MeOH}$ without stirring at room temperature.

\section{Conclusions}

In conclusion we reported the straightforward preparation of a new dimeric neutral copper(I) complex embedded with phosphinesulfonate chelate and demonstrated the photoluminescence properties of this new scaffold in solid state. Facile diversification with various bipyrimidine derivatives highlighted its potential for the preparation of the corresponding heterotopic neutral copper(I) complexes. A series of complexes differing by the nature of the phosphine as well as by substitution of methanol molecules with other nucleophiles is currently underway to gain a deeper understanding of these solvent-dependent reversible photophysical properties.

\section{Experimental}

\section{General considerations}

All reactions were carried out under argon atmosphere using Schlenk tube techniques. Unless stated, reagents were purchased from commercial sources and used as received. Solvents (toluene, dichloromethane and diethyl ether) were dried using a MBraun Solvent Purification System. Methanol HPLC grade was degased and used as received. NMR spectra were recorded at room temperature on a Bruker Avance $(400 \mathrm{MHz})$ spectrometer and reported in ppm with reference to $\mathrm{CDCl}_{3}(7.26 \mathrm{ppm}), \mathrm{CD}_{2} \mathrm{Cl}_{2}$

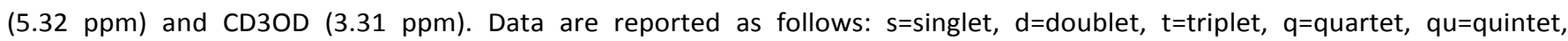
sept=septuplet, $\mathrm{m}=$ multiplet, $\mathrm{br}=$ broad. Coupling constants are reported in $\mathrm{Hz} .{ }^{13} \mathrm{C} \mathrm{NMR}$ spectra were recorded at $100.6 \mathrm{MHz}$ on the same spectrometer and reported in ppm with reference to $\mathrm{CDCl}_{3}$ (76 ppm), $\mathrm{CD}_{2} \mathrm{Cl}_{2}$ (53.8 ppm) and $\mathrm{CD}_{3} \mathrm{OD}(49.0 \mathrm{ppm}$ ).

Solid state absolute quantum yield and optical microscopy 
Solid state absolute quantum yield were measured with a Hamamatsu C9920-03G system. Optical microscopy investigations were performed on a Nikon H600L polarising microscope equipped with a Linkam "liquid crystal pro system" hotstage. The microscope is also equipped with a UV irradiation source (Hg Lamp, $\lambda=340-380 \mathrm{~nm}$ ) and an ocean optic USB 2000+ UV-Vis-NIR spectrophotometer based on CCD detection technology. This set-up allows the recording of luminescence spectra on solids, liquids, liquid crystalline materials and gels from $-196^{\circ} \mathrm{C}$ up to $420^{\circ} \mathrm{C}$ between 350 and $1100 \mathrm{~nm}$.

X-ray Crystallography

Suitable crystals for the X-ray analyses were obtained by solvents diffusion technique. Data set were collected on D8 VENTURE Bruker AXS and a APEXII, Bruker-AXS diffractometers with a Mo-K $\alpha$ radiation $(\lambda=0.71073 \AA$ ). The structures were solved by direct methods using the SIR97 program, ${ }^{[34]}$ and then refined with full-matrix least-square methods based on $F^{2}$ (SHELXL-97) ${ }^{[35]}$ with the aid of the WINGX ${ }^{[36]}$ program. In some cases, the contribution of the disordered solvents to the calculated structure factors was estimated following the BYPASS algorithm, ${ }^{[37]}$ implemented as the SQUEEZE option in PLATON. ${ }^{[38]}$

\section{Synthesis of $\mathrm{Cu}-1:\left\{\mathrm{Cu}_{2}\right.$ (DPPBS) $\left.2.2 \mathrm{MeOH}\right\}$}

DiphenylPhosphinoBenzeneSulfonic Acid DPPBSA ( $200 \mathrm{mg}, 0.58 \mathrm{mmol}, 1$ eq.) was added to degazed methanol ( $3 \mathrm{~mL}$ ) in a Schlenk tube. After 5 minutes stirring, $\mathrm{Cu}_{2} \mathrm{O}(42 \mathrm{mg}, 0.29 \mathrm{mmol}, 0.5$ eq.) was added and the resulting mixture was stirred at room temperature for 10 minutes then heated at $70{ }^{\circ} \mathrm{C}$ for 5 minutes to dissolve the resulting white precipitate followed by cannulation to remove the remaining inorganic salt $\left(\mathrm{Cu}_{2} \mathrm{O}\right)$. After cooling at room temperature, the solution was concentrated to $1 \mathrm{~mL}$. The resulting colorless crystals were retrieved by filtration under inert atmosphere and washed with methanol to afford the colourless $\mathbf{C u}-\mathbf{1}$ complex along with one uncoordinated methanol molecule (152 $\mathrm{mg}, 59 \%)$.

Solubility: crystal form low solubility in $\mathrm{CH}_{2} \mathrm{Cl}_{2}, \mathrm{CHCl}_{3}$, toluene; moderate to good solubility in methanol. Stability: Air sensitive dimer which slowly turn blue/green in the presence of oxygen. ${ }^{1} \mathrm{H} \mathrm{NMR}\left(400 \mathrm{MHz}, \mathrm{CD}_{3} \mathrm{OD}\right): \delta 8.15(\mathrm{dd}, J=7.2,2.9 \mathrm{~Hz}, 1 \mathrm{H}), 7.50$ $(\mathrm{td}, J=7.6,1.3 \mathrm{~Hz}, 1 \mathrm{H}), 7.41-7.29(\mathrm{~m}, 11 \mathrm{H}), 7.02(\mathrm{t}, J=7.7 \mathrm{~Hz}, 1 \mathrm{H}), 3.33(2 \mathrm{MeOH}) ;{ }^{31} \mathrm{P}\left\{{ }^{1} \mathrm{H}\right\} \mathrm{NMR}\left(162 \mathrm{MHz}, \mathrm{CD}_{3} \mathrm{OD}\right): \delta-5.36 ;{ }^{13} \mathrm{C}$ $\left\{{ }^{1} \mathrm{H}\right\}$ NMR (100 MHz, CD $\left.{ }_{3} \mathrm{OD}\right): \delta 150.70(\mathrm{br}, \mathrm{Cq}), 136.10(\mathrm{~s}), 134.77$ (d, J=12 Hz), $134.68(\mathrm{~d}, J=15 \mathrm{~Hz}), 134.61(\mathrm{~d}, J=10 \mathrm{~Hz}), 134.01$ (d, $J=39 \mathrm{~Hz}$ ), 131.08 (s), 131.35, 131.30, 131.17, 129.81, 129.74, 129.31, 49.0; Elemental Analysis for Cu-1.1 MeOH, Theoretical: C, 51.71; H, 4.45; S, 7.08, Measured: C, 51.20; H, 4.58; S, 6.76; CCDC 1417484 contains the supplementary crystallographic data for Cu-1. HRMS (ESI) [Cu(DPPBS) Na] $\left(\mathrm{C}_{18} \mathrm{H}_{14} \mathrm{O}_{3} \mathrm{NaPSCu}\right) \mathrm{Th:} 426.95895$; Exp: 426.9591.

\section{Synthesis of $\mathrm{Cu}-2:\{\mathrm{Cu}(\mathrm{DPPBS})(\mathrm{tmbpm})\}$}

Cu-1 (20 mg, $0.022 \mathrm{mmol}, 1$ eq.) was dissolved in dry and degazed methanol $(4 \mathrm{~mL})$. To the resulting solution $4,4^{\prime}, 6,6^{\prime}$ tetramethyl-2,2'-bipyrimidine (tmbpm) $(14.7 \mathrm{mg}, 0.068 \mathrm{mmol}, 3 \mathrm{eq}$.) was added directly and the solution turn immediately yellow. After 30 minutes stirring at room temperature, the resulting mixture was concentrated in vacuo. The solid was washed with a toluene: $n$-hexane solution to remove the remaining tmbpm followed by crystallization using solvent diffusion technique (toluene/ $n$-hexane) to afford the expected mononuclear $\mathbf{C u - 2}$ complex as yellow crystals (15 $\mathrm{mg}, 53 \%)$.

${ }^{1} \mathrm{H}$ NMR $\left(400 \mathrm{MHz}, \mathrm{CD}_{2} \mathrm{Cl}_{2}\right): \delta 8.31$ (ddd, $\left.J=7.8,4.5,1.3 \mathrm{~Hz}, 1 \mathrm{H}\right), 7.55(\mathrm{t}, J=7.6 \mathrm{~Hz}, 1 \mathrm{H}), 7.40-7.13(\mathrm{~m}, 13 \mathrm{H}), 7.10(\mathrm{t}, \mathrm{J}=7.9 \mathrm{~Hz}, 1 \mathrm{H})$, 2.59 (brs, $12 \mathrm{H}) ;{ }^{31} \mathrm{P}\left\{{ }^{1} \mathrm{H}\right\} \operatorname{NMR}\left(162 \mathrm{MHz}, \mathrm{CD}_{2} \mathrm{Cl}_{2}\right): \delta-3.27 ;{ }^{13} \mathrm{C}\left\{{ }^{1} \mathrm{H}\right\} \mathrm{NMR}\left(100 \mathrm{MHz}, \mathrm{CD}_{2} \mathrm{Cl}_{2}\right): \delta 168.72$ (s, Cq.), 165.57 (s, Cq.), 160.44 (s, Cq.), 150.91 (d, J=17.7 Hz, Cq.), 136.29 (Cq.), 134.57 (d, J=12 Hz), 134.34 (d, J= 15.6 Hz), 134.15 (d, J=8.2 Hz), 132.17 , $130.64(\mathrm{~d}, J=1.3 \mathrm{~Hz}), 130.24$ (d, J=4.6 Hz), 130.17 (d, J=1.4 Hz), 129.59 (s), 129.09 (d, J=6.7 Hz), 128.73 (d, J=10.0 Hz), 128.18 (s), 118.73 (s), 25.55 (s); Elemental Analysis for $\mathrm{Cu}-2.2 \mathrm{CH}_{2} \mathrm{Cl}_{2}$, Theoretical: C, 48.71; H, 4.09; N, 7.10; S, 4.06, Measured: C, 49.10; $\mathrm{H}$, 4.32; N, $7.02 \mathrm{~S}, 3.96$; CCDC 1417461 contains the supplementary crystallographic data for Cu-2. HRMS (ESI) [Cu-2] $\left(\mathrm{C}_{30} \mathrm{H}_{28} \mathrm{~N}_{4} \mathrm{O}_{3} \mathrm{PSCu}\right)$ Th: 618.09103; Exp: 618.0909.

\section{Synthesis of $\mathrm{Cu}-3:\left\{\mathrm{Cu}_{2}(\mathrm{DPPBS})_{2}(\mathrm{tmbpm})\right\}$}

Cu-1 (50 mg, $0.057 \mathrm{mmol}, 1$ eq.) was dissolved in dry and degazed methanol $3 \mathrm{~mL}$. To the resulting solution 4,4',6,6'-tetramethyl2,2'-bipyrimidine (tmbpm) (12.3 $\mathrm{mg}, 0.05 \mathrm{mmol}, 1$ eq.) was slowly added and the solution turn orange. After one hour stirring at room temperature the orange/red mixture was concentrated in vacuo. $\mathrm{Crystallization} \mathrm{by} \mathrm{solvent} \mathrm{diffusion} \mathrm{technique}\left(\mathrm{CH}_{2} \mathrm{Cl}_{2} / n\right.$ hexane) gives the expected red complex $\mathbf{C u}-3$ (22 mg, 38\%) whereas the resulting yellow solution contain the mononuclear side product $\mathrm{Cu}-2$.

${ }^{1} \mathrm{H}$ NMR $\left(400 \mathrm{MHz}, \mathrm{CD}_{2} \mathrm{Cl}_{2}\right): \delta 8.34$ (ddd, 7.7, 4.4, 1.3 Hz, 2H), 7.61-7.56 (m, 4H), 7.46-7.06 (m, $\left.24 \mathrm{H}\right), 2.58(\mathrm{~s}, 12 \mathrm{H}) ;{ }^{31} \mathrm{P}\left\{{ }^{1} \mathrm{H}\right\} \mathrm{NMR}$ $\left(162 \mathrm{MHz}, \mathrm{CD}_{2} \mathrm{Cl}_{2}\right.$ ): $\delta$-2.68; Owing to the low solubility and instability of $\mathrm{Cu}-3$ in common solvents like $\mathrm{CD}_{2} \mathrm{Cl}_{2}, \mathrm{CDCl}_{3}, \mathrm{C}_{6} \mathrm{D}_{6}$ and DMSO prevented clear characterization by ${ }^{13} \mathrm{C}\{1 \mathrm{H}\} \mathrm{NMR}$ measurements; CCDC 1417460 contains the supplementary crystallographic data for $\mathbf{C u}$-3.

Synthesis of Cu-4 : \{Cu(DPPBS)(PhMebpm)\} 
DPPBSA (100 mg, $0.29 \mathrm{mmol}, 1$ eq.) was dissolved in dry and degazed methanol $3 \mathrm{~mL}$ followed by the addition of $\mathrm{Cu}_{2} \mathrm{O}(21 \mathrm{mg}$, $0.14 \mathrm{mmol}, 0.5$ eq.). The resulting mixture was heated at $70{ }^{\circ} \mathrm{C}$ for ten minutes then cooled at room temperature. After the apparition of a white precipitate, 4,4'-Diphenyl-6,6'-dimethyl-2,2'-bipyrimidine (PhMebpm) (98 mg, $0.29 \mathrm{mmol}, 1 \mathrm{eq}$.) was added directly and the solution turn immediately orange. After 30 minutes stirring at room temperature the orange/red solid was dissolved and cannulated followed by concentration in vacuo. Crystallization by solvent diffusion technique $\left(\mathrm{CH}_{2} \mathrm{Cl} / 2 \mathrm{n}\right.$-hexane) gives the expected complex Cu-4 (120 mg, 55\%) as red crystals. ${ }^{1} \mathrm{H}$ NMR $\left(400 \mathrm{MHz}, \mathrm{CD}_{2} \mathrm{Cl}_{2}\right): \delta 8.38-8.34(\mathrm{~m}, 5 \mathrm{H}), 7.91(\mathrm{~s}, 2 \mathrm{H})$, 7.60-7.53 (m, 7H), 7.40-7.36 (m, 3H), 7.31-7.27 (m, 4H), 7.22-7.17 (m, 4H), 7.05-7.03 (m, 1H), 2.67 (s, 6H); ${ }^{31} \mathrm{P}\left\{{ }^{1} \mathrm{H}\right\} \mathrm{NMR}(162 \mathrm{MHz}$, $\mathrm{CD}_{2} \mathrm{Cl}_{2}$ ): $\delta-3.32 ;{ }^{13} \mathrm{C}\left\{{ }^{1} \mathrm{H}\right\}$ NMR (100 MHz, $\mathrm{CD}_{2} \mathrm{Cl}_{2}$ ): $\delta 168.72$ (s, Cq.), 165.57 (s, Cq.), 160.44 (s, Cq.), 150.91 (d, J=17.7 Hz, Cq.), 136.29 (Cq.), 134.57 (d, J=12 Hz), 134.34 (d, J= 15.6 Hz), 134.15 (d, J= 8.2 Hz), 132.17, 130.64 (d, J= 1.3 Hz), 130.24 (d, J= 4.6 Hz), 130.17 (d, $J=1.4 \mathrm{~Hz}$ ), 129.59 (s), 129.09 (d, J=6.7 Hz), 128.73 (d, J=10.0 Hz), 128.18 (s), 118.73 (s), 25.55 (s); Elemental Analysis for $\mathrm{Cu}-4 . \mathrm{CH}_{2} \mathrm{Cl}_{2}$, Theoretical: $\mathrm{C}, 59.46 ; \mathrm{H}, 4.14 ; \mathrm{N}, 6.76 ; \mathrm{S}, 3.87$, Measured: $\mathrm{C}, 59.82 ; \mathrm{H}, 4.21 ; \mathrm{N}, 6.63 ; \mathrm{S}, 3.55 ; \mathrm{CCDC} 1417462$ contains the supplementary crystallographic data for $\mathbf{C u}-\mathbf{4}$.

\section{Reversible photoluminescence experiment}

Cu-1 (30 mg) was powdered into a Schlenk tube under inert atmosphere. The resulting white powder was then heated at $70^{\circ} \mathrm{C}$ under vacuum for 20 mins and then allowed to cooled at room temperature naturally. The Schlenk tube was then refilled with an atmosphere of argon followed by the addition of $100 \mu \mathrm{L}$ of degased methanol.

\section{References and notes}

1 (a) C. L. Linfoot, P. Richardson, T. E. Hewat, O. Moudam, M. M. Forde, A. Collins, F. White and N. Robertson, Dalton Trans., 2010, 39, 8945; (b) S.-P. Luo, E. Mejia, A. Friedrich, A. Pazidis, H. Junge, A.-E. Surkus, R. Jackstell, S. Denurra, S. Gladiali, S. Lochbrunner and M. Beller, Angew. Chem. Int. Ed., 2013,52, 419.

2 (a) X.-L. Xin, M. Chen, Y.-b. Ai, F.-l. Yang, X.-L. Li and F. Li, Inorg. Chem., 2014, 53, 2922; (b) C. Santini, M. Pellei, V. Gandin, M. Porchias, F. Tisato and C. Marzano, Chem. Rev., 2014, 114, 815; (c) V. Sathish, A. Ramdass, P. Thanasekaran, K.-L. Lu and S. Rajagopal, J. Photochem. Photobiol. C: Photochem Rev., 2015, 23, 25.

3 (a) C. S. Smith, C. W. Branham, B. J. Marquardt and K. R. Mann, J. Am. Chem. Soc., 2010, 132, 14079.

4 (a) H. Yersin, A. F. Rausch, R. Czerwienic, T. Hofbeck and T. Fischer, Coord. Chem. Rev., 2011, 255, 2622; (b) E. Cariati, E. Lucenti, C. Botta, U. Giovanella, D. Marinotto and S. Righetto, Coord. Chem. Rev., 2016, 306, 566.

5 S. Paria and O. Reiser, ChemCatChem, 2014, 6, 2477.

6 V. Wing-Wah Yam, V. K.-M. Au and S. Y.-L. Leung, Chem. Rev., 2015, 115, 7589.

7 (a) D. G. Cuttell, S.-M. Kuang, P. E. Fanwick, D. R. McMillin and R. A. Walton, J. Am. Chem. Soc., 2002, 124, 6; (b) Q. Zhang, Q. Zhou, Y. Cheng, L. Wang, D. Ma, X. Jing and F. Wang, Adv. Mater. 2004, 16, 432; (c) N. Armaroli, G. Accorsi, M. Holler, O. Moudam, J.F. Nierengarten, Z. Zhou, R. T. Wegh and R. Welter, Adv. Mater. 2006, 18, 1313;(d) G. F. Manbeck, W. W. Brennessel and R. Eisenberg, Inorg. Chem., 2011, 50, 3431; (e) M. Nishikawa, K. Nomoto, S. Kume, K. Inoue, M. Sakai, M. Fujii and H. Nishihara, J. Am. Chem. Soc., 2010, 132, 9579; (f) A. Kaeser, M. Mohankumar, J. Mohanraj, F. Monti, M. Holler, J.-J. Cid, O. Moudam, I. Nierengarten, L. Karmazin-Brelot, C. Duhayon, B. Delavaux-Nicot, N. Armaroli and J.-F. Nierengarten, Inorg. Chem., 2013, 52, 12140; (g) R. Czerwieniec and H. Yersin, Inorg. Chem., 2015, 54, 4322; (h) E. Mejia, S.-P. Luo, M. Karnahl, A. Friedrich, S. Tschierlei, A.-E. Surkus, H. Juge, S. Gladiali, S. Lochbrunner and M. Beller, Chem. Eur. J. , 2013, 19, 15972; (i) N. S. Murray, S. Keller, E. C. Constable, C. E. Housecroft, M. Neuburger and A. Prescimone, Dalton Trans., 2015, 44, 7626 (j) Q. Zhang, X-L. Chen, J. Chen, X-Y. Wu, R. Yu and C.-Z. Lu, Dalton Trans., 2015, 44, 10022.

8 B.-T. Ahn and D. R. McMillin, Inorg. Chem., 1978, 17, 2253.

9 M. Mohankumar, M. Holler, J.-F. Nierengarten and J.-P. Sauvage, Chem. Eur. J., 2012, 18, 12192.

10 (c) R. Visbal and C. Gimeno, Chem. Soc. Rev., 2014, 43, 3551.

11 (a) V. A. Krylova, P. I. Djurovich, M. T. Whited and M. E. Thompson, Chem. Commun., 2010, 46, 6696; (b) R. Marion, F. Sguerra, F. Di Meo, E. Sauvageot, J.-F. Lohier, R. Daniellou, J.-L. Renaud, M. Linares, M. Hamel and S. Gaillard, Inorg. Chem., $2014,53,9181$.

12 (a) D. Li, R.-Z. Li, Z. Ni, Z.-Y. Qi, X.-L. Feng and J.-W. Cai, Inorg. Chem. Commun., 2003, 6, 469; (b) M. G. Crestani, G. F. Manbeck, W. W. Brennessel, T. M. McCormick and R. Eisenberg, Inorg. Chem., 2011, 50, 7172; (c) M. Hashimoto, S. Igawa, M. Yashima, I. Kawata, M. Hoshino and M. Osawa, J. Am. Chem. Soc., 2011, 133, 10348; (d) J. G. Malecki, A. Maron, J. Palion, J. E. Nycz and M. Szala, Transition Met. Chem., 2014, 39, 755. (e) T. F. Van Dijkman, H. M. De Bruijn, M. A. Siegler and E. Bouwman, Eur. J. Inorg. Chem., 2015, 5387.

13 (a) J. Díez, M. P. Gamasa, J. Gimeno, A. Tiripicchio and M. Tiripicchio Camellini, J. Chem. Soc. Dalton Trans., 1987, 1275; (b) D. Li, C.-M. Che, W.-T. Wong, S.-J. Shieh and S.-M. Peng, J. Chem. Soc. Dalton Trans., 1993, 653; (c) S. Kitagawa, M. Kondo, S. Kawata, S. Wada, M. Maekawa and M. Munakata, Inorg. Chem., 1995, 34, 1455; (d) P. D. Harvey, M. Drouin and T. Zhang, Inorg. Chem., 1997, 36, 4998; (e) M. Schwach, H. -D. Hausen and W. Kaim, Chem. Eur. J., 1996, 2, 446; (g) X. Zhang, L. Song, M. Hong, H. Shi, K. Xu, Q. Lin, Y. Zhao, Y. Tian, J. Sun, K. Shu and W. Chai, Polyhedron, 2014, 81, 687.

Electronic Supplementary Information (ESI) available: Comparison of the bond lengths deduced from x-ray analysis and computational geometry optimizations, comparison between the computed and the experimental absorption spectra. 1D and 2D NMR spectra of the compounds. See DOI: 10.1039/x0xx00000x 
14 P. C. Ford, E. Cariati and J. Bourassa, Chem. Rev., 1999, 99, 3625

15 (a) H. D. Hardt and A. Pierre, Inorg. Chem. Acta, 1977, 25, L59; (b) N. P. Rath, E. M. Holt and K. Tanimura, Inorg. Chem., 1985, 24, 3934; (c) K. R. Kyle, C. K. Ryu, J. A. DiBenedetto and P. C. Ford, J. Am. Chem. Soc., 1991, 113, 2954; (d) S. Perruchas, C. Tard, X. F. Le Goff, A. Fargues, A. Garcia, S. Kahlal, J.-Y. Saillard, T. Gacoin and J.-P. Boilot, Inorg. Chem., 2011, 50, 10682; (e) S. A. Bhat, J. T. Mague and M. S. Balakrischna, Eur. J. Inorg. Chem., 2015, 3949; (f) Q. Benito, X. F. Le Goff, G. Nocton, A. Fargues, A. Garcia, A. Berhault, S. Kahlal, J.-Y. Saillard, C. Martineau, J. Trebosc, T. Gacoin, J.-P. Boilot and S. Perruchas, Inorg. Chem., 2015, 54, 4483.

16 (a) N. P. Rath, J. L. Maxwell and E. M. Holt, J. Chem. Soc. Dalton Trans., 1986, 2449; (b) M. Henary, J. L. Wootton, S. I. Khan and J. I. Zink, Inorg. Chem., 1997, 36, 796; (c) A. A. Khandar, R. J. Butcher, M. Abedi, S. A. Hosseini-Yazdi, M. Akkurt and M. N. Tahir, Polyhedron, 2010, 29, 3178; (d) K. Tsuge, Y. Chishina, H. Hashiguchi, Y. Sasaki, M. Kato, S. Ishizaka and N. Kitamura, Coord. Chem. Rev., 2016, 306, 636.

17 C. Bizzari, C. Strabler, J. Prock, B. Trettenbrein, M. Ruggenthaler, C.-H. Yang, F. Polo, A. lordache, P. Brüggeller and L. De Cola, Inorg. Chem., 2014, 53, 10944.

18 P. D. Harvey, Inorg. Chem., 1995, 34, 2019;

19 (a) S. B. Harkins and J. C. Peters, J. Am. Chem. Soc., 2005, 127, 2030 ; (b) J. C. Deaton, S. C. Switalski, D. Y. Kondakov, R. H. Young, T. D. Pawlik, D. J. Giesen, S. B. Harkins, A. J. M. Miller, S. F. Mickenberg and J. C. Peters, J. Am. Chem. Soc., $2010,132,9499$.

20 (a) D. M. Zink, M. Bächle, T. Baumann, M. Nieger, M. Kühn, C. Wang, W. Klopper, U. Monkowius, T. Hofbeck, H. Yersin and S. Bräse, Inorg. Chem., 2013, 52, 2292; (b) D. M. Zink, D. Volz, T. Baumann, M. Mydlak, H. Flügge, J. Friedrichs, M. Nieger and S. Bräse, Chem. Mater., 2013, 25, 4471; (c) D. M. Zink, L. Bergmann, D. Ambrosek, M. Wallesh, D. Volz and M. Mydlak, Trans. Mater. Res., 2014, 1, 015003; (d) X. Chen, Z. Li, F. Yanan and H. Grützmacher, Eur. J. Inorg. Chem., 2016, DOI:10.1002/ejic.201500933.

21 D. M. Knotter, G. Blasse, J. P. M. van Vliet and G. van Koten, Inorg. Chem., 1992, 31, 2196.

22 B. Liu, C. Chen, Y. Zhang, X. Liu and W. Chen, Organometallics, 2013, 32, 5451.

23 (a) J. Vela, G. R. Lief, Z. Shen and R. F. Jordan, Organometallics, 2007, 26, 6624; (b) Z. Cai, Z. Shen, X. Zhou and R. F. Jordan, ACS Catal., 2012, 2, 1187 (c) F. Jiang, K. Yuan, M. Achard and C. Bruneau, Chem. Eur. J., 2013, 19, 10343; (d) O. Bashir, L. Piche and J. P. Claverie, Organometallics, 2014, 33, 3695; (e) M. Li, H. Song and B. Wang, Organometallics, 2015, 34, 1969.

24 (a) A. Nakamura, S. Ito and K. Nozaki, Chem. Rev., 2009, 109, 5215; (b)A. Nakamura, T. M. J. Anselment, J. Claverie, B. Goodall, R. F. Jordan, S. Mecking, B. Rieger, A. Sen, P. W. N. M. van Leeuwen and K. Nozaki, Acc. Chem. Res., 2013, 46, 1438; (c) F. Jiang, M. Achard and C. Bruneau, Advances in Organometallic Chemistry; Perez, P. J., Ed.; Academic Press: Burlington, $2014 ; 62$, pp 159.

25 For an interesting report with $\mathrm{Cu}(\mathrm{II})$ see : (a) B. Oelkers, Eur. J. Inorg. Chem., 2014, 5838; For an unchelated form of NHCsulfonates with Copper(I) see : (b) Y. Shi, B. Jung, S. Torker and A. H. Hoveyda, J. Am. Chem. Soc., 2015, 137, 8948.

26 R. E. Murray and W. V. Charleston,. US Patent 1987, 4,689,437.

27 Y. Hattori, M. Nishikawa, T. Kusamoto, S. Kume and H. Nishihara, Inorg. Chem., 2014, 53, 2831.

28 Calculation details are included in the supporting information.

29 C. Latouche, D. Skouteris, F. Palazzetti and V. Barone, J. Chem. Theory Comput., 2015, 11, 3281.

30 To address this issue one could change the functional and use Long-Range corrected with a higher \%HF (i.e. CAM-B3LYP/LCWPBE).

31 (a) C.-M. Che, Z. Mao, V. M. Miskowski, M.-C. Tse, C.-K. Chan, K.-K. Cheung, D. L. Phillips and K.-H. Leung, Angew. Chem. Int. Ed., 2000, 39, 4084; (b) D.L. Phillips, C.-M. Che, K. H. Leung, Z. Mao and M.-C. Tse, Coord. Chem. Rev., 2005, 249, 1476; (c) Y. Chen, J.-L. Li, G. S. M. Tong, W. Lu, W.-F. Fu, S.-W. Lai and C.-M. Che, Chem. Sci., 2011, 2, 1509.

32 (a) G. Zeng, S. Xing, X. Han, B. Xin, Y. Yang, X. Wang, G. Li, Z. Shi and S. Feng, RSC Adv., 2015, 5, 40792; for a recent report on methanol detection see : (b) N. Yosjinari, T. Shimizu, K. Nozaki and T. Konno, Inorg. Chem., 2016, DOI: 10.1021/acs.inorgchem.5b02363.

33 (a) J. R. Shakirova, E. V. Grachova, A. S. Melnikov, V. V. Gurzhiy, S. P. Tunik, M. Kaukka, T. A. Pakkanen and I. O. Koshevoy, Organometallics, 2013, 32, 4061 (a) T. Hayashi, A. Kobayashi, H. Ohara, M. Yoshida, T. Matsumoto, H.-C. Chang and M. Kato, Inorg. Chem., 2015, 54, 8905

34 A. Altomare, M. C. Burla, M. Camalli, G. Cascarano, C. Giacovazzo, A. Guagliardi, A. G. G. Moliterni, G. Polidori and R. Spagna, J. Appl. Cryst., 1999, 32, 115.

35 Sheldrick G.M., Acta Cryst. ,2008, A64 112.

36 L. J. Farrugia, J. Appl. Cryst., 2012, 45, 849.

37 P. v.d. Sluis and A.L. Spek, Acta Cryst., 1990, A46, 194.

38 A. L. Spek, J. Appl. Cryst.,2003, 36, 7. 